\title{
Boehler-Gissane Angles In Patients Who Admitted To Our Hospital: How are Boehler and Gissane Angles in Feet with Pes Planus?
}

\author{
Hastanemize Bașvuran Hastalarda Böhler ve Gissane Açıları: Boehler ve Gissane Açıları \\ Pes Planuslu Ayaklarda Nasıldır?
}

\author{
Kadri Yıldız', Türkhun Çetin² \\ ${ }^{1}$ Department of Orthopaedics and Traumatology; ${ }^{2}$ Department of Radiology, Kafkas University Medical School of Medicine, Kars, Turkey
}

\begin{abstract}
Aim: This study aims to determine normal ranges on BA and GA of patient population which admitted to our hospital from Kars province and around. The secondary purpose is to reveal the relationship between $B A, G A$ and pes planus deformity.

Material and Method: The study groups were divided into two randomized controlled groups as Group $A$ and Group B. Group A consisted patients without pes planus. And Group B consisted patients with pes planus. Group A consisted 107 (37 males, 70) and Group $B$ consisted 26 (12 females, 14 males) patients. The measurements were made by a senior orthopedic specialist 14 year-experienced in Group A. And the measurements for Group B were made by a senior orthopedic specialist 14 year-experienced and by a senior radiologist specialist 25 year-experienced. Group $B$ was evaluated for reliability tests. The Intraclass Classification Correlations (ICC) values were determined.

Results: There was no difference between the groups in terms of gender distribution according to the chi-square test $(p=0.272)$. In Group $A$, the mean in $B A$ were $36,77^{\circ} \pm 3,67^{\circ}$ for right feet; $33,23^{\circ} \pm 7,20^{\circ}$ for left feet. The mean in $G A$ were $110,99^{\circ} \pm 10,18^{\circ}$ for right feet; $108,96^{\circ} \pm 9,18^{\circ}$ for left feet. In Group $B$, the mean in $B A$ were $36,01^{\circ} \pm 7,01^{\circ}$ for right feet; $35,40^{\circ} \pm 6,43^{\circ}$ for left feet. The mean in $G A$ were $116,02^{\circ} \pm 8,57^{\circ}$ for right feet; $111,48^{\circ} \pm 6,23^{\circ}$ for left feet. There was no statistical difference between groups and sides ( $p=0.362)$. The ICC values for $B A$ in right, $B A$ in left, $G A$ in right, $G A$ in left were 0.996, 0.997, 0.993, 0.987 respectly. All values were significant.

Conclusion: The values of BA and GA in the population that admitted to our hospital were in normal ranges. No relationships were not found between $B A, G A$ and pes planus deformity. The reliable values on $B A$ and $G A$ between two observers were detected.
\end{abstract}

Key words: Boehler angle; Gissane angle; pes planus; reliability

\section{ÖZET}

Amaç: Bu çalıșma, Kars ili ve çevresinden hastanemize bașvuran hastalarda Böhler (BA) ve Gissane (GA) açısındaki normal aralıkları belirlemeyi amaçlamaktadır. Íkincil amaç $B A, G A$ ve pes planus deformitesi arasındaki ilișkiyi ortaya koymaktır.

Materyal ve Metot: Iki randomize kontrollü grup, Grup A ve Grup $B$ olmak üzere çalıșma grubu olarak iki alt gruba ayrıldı. Grup $A$, pes planus deformitesi olmayan hastalardan olușmaktaydı. $B$ grubu ise pes planus olan hastalardan olușuyordu. A grubunda 107 hasta mevcuttu (37 kadın, 70 erkek). Grup B'de ise pes planus deformitesi olan 26 hasta (12 kadın, 14 erkek) vardı. Ölçümler, Grup A'da 14 yıllık tecrübeli kıdemli bir ortopedi uzmanı tarafından yapıldı ve $B$ Grubu için ölçümler, 14 yıllık tecrübeli kıdemli bir ortopedi uzmanı ve 25 yıllık deneyimli bir radyoloji uzmanı tarafından yapıldı. B grubu güvenilirlik testleri için değerlendirildi. Sınıf içci Sınıflama Korelasyonları (Intraclass Classification Correlations, ICC) değerleri belirlendi.

Bulgular: Ki-kare testine göre gruplar arasında cinsiyet dağııımı açısından fark yoktu ( $p=0.272$ ). Grup $A$ 'da sağ ayaklarda $B A$ ortalaması $36,77^{\circ} \pm 3,67^{\circ}$ idi. BA'da sol ayak için ortalama $33,23^{\circ} \pm 7,20^{\circ}$ idi. Sağ ayaklar için GA'da ortalama $110,99^{\circ} \pm 10,18^{\circ}$ idi. Sol ayaklar için GA'da ortalama $108,96^{\circ} \pm 9,18^{\circ}$ idi. B Grubunda sağ ayaklarda $B A$ ortalaması $36,01^{\circ} \pm 7,01^{\circ}$ idi. BA'da sol ayak için ortalama $35,40^{\circ} \pm 6,43^{\circ}$ idi. Sağ ayaklar için GA'da ortalama $116,02^{\circ} \pm 8,57^{\circ}$ idi. Sol ayaklarda $G A^{\prime}$ da ortalama $111,48^{\circ} \pm 6,23^{\circ}$ idi. Gruplar ve taraflar arasında istatistiksel olarak anlamlı fark yoktu $(p=0.362)$. ICC değerleri, sağda $B A$, solda $B A$, sağda $G A$, solda $G A$ için sırasıyla 0.996, 0.997, 0.993, 0.987 idi. Güvenilirlik testleri için tüm değerler istatistiksel olarak anlamlıydı.

Sonuç: Hastanemize bașvuran popülasyonda, BA ve GA'nın değerleri normal aralıklarda tespit edildi. BA, GA ve pes planus deformitesi arasında bir ilișki bulunamadı. BA ve GA'da iki gözlemci arasında güvenilir değerler tespit edildi.

Anahtar kelimeler: Boehler açısl; Gissane açısı; pes planus; güvenilirlik

Iletișim/Contact: Kadri Yildız, Kafkas Üniversitesi Tip Fakültesi Ortopedi ve Travmatoloji Anabilim Dal, 36100 Kars, Türkiye • Tel:05385450559 • E-mail: drkadri1980@hotmail.com • Geliș/Received:04.07.2019 • Kabul/Accepted: 16.12.2019

ORCID: Kadri Yuldız, 0000-0002-8164-7687 • Türkhun Çetin, 0000-0003-0209-4218 


\section{Introduction}

The calcaneus is the biggest tarsal bone. In all fractures, tarsal fractures are about 2\%. Calcaneal fractures account for $50-60 \%$ of tarsal fractures. Less than $10 \%$ is open fractures ${ }^{1}$. Boehler and Gissane angles are the corner point for calcaneal fractures. Especially, Boehler angle (BA) is the predictor of this fracture type $e^{2-4}$. In 1931, Dr. Lorenz Boehler defined this angle as "tuber angle" with a normal range between $30^{\circ}-35^{\circ}$. BA predicts calcaneal fractures ${ }^{5}$. Also, Gissane angle predicts calcaneal fractures as like Boehler, too. And its normal range is defined between $95^{\circ}-152^{\circ} 6,7$. At the literature, there are some studies for BA $\left(20^{\circ}-46^{\circ}\right)$ and GA $\left(100^{\circ}\right.$ $133^{\circ}$ ) by normal ranges ${ }^{4,5,8,9}$.

This study aims to determine normal ranges on BA and GA of Caucasian people in Kars in Turkey. And also, the secondary purpose is to reveal the relationship between BA, GA and pes planus deformity.

\section{Materials and Methods}

A randomized controlled group was chosen at our clinic between November 2017 and November 2018 for BA and GA measurement. The study groups were divided into two sub-groups as Group A and Group B. Group A consisted patients without pes planus deformity. And Group B consisted patients with pes planus population. Secondary foot deformities as tarsal coalition, deformity or fusion were excluded from the Group A. The study group consisted of 214 pairs digital lateral foot or ankle radiography records of 107 patients. It consisted of 37 males, 70 females and the mean in age was 25,44 (min: 6-max:74). And Group B consisted of 52 pairs foot of 26 patients with pes planus deformity as 12 females and 14 males and the mean in age was 22.52 ( $\min : 6-\max : 65)$.

BA and GA were measured according to referred sources. Boehler's angle (BA) is referred to as tuber Angle (also called a calcaneal angle, critical angle and tuber joint angle) at the literature ${ }^{10-12}$. BA is drawn by the intersection of two lines as the first one was laid on the most cephalic part of the posterior process of the calcaneus bone and the most cephalic or top point of the posterior facet. The second one was laid on the most cephalic or top point of the posterior facet of the calcaneus and the top point of the calcaneus bone that forms the articular side for cuboid bone. The normal range is $20^{\circ}-40^{\circ}$. Lesser than $20^{\circ}$ angles indicate calcaneal fractures. Another description of Boehler angle is mentioned by tangential methods ${ }^{13}$. At another paper

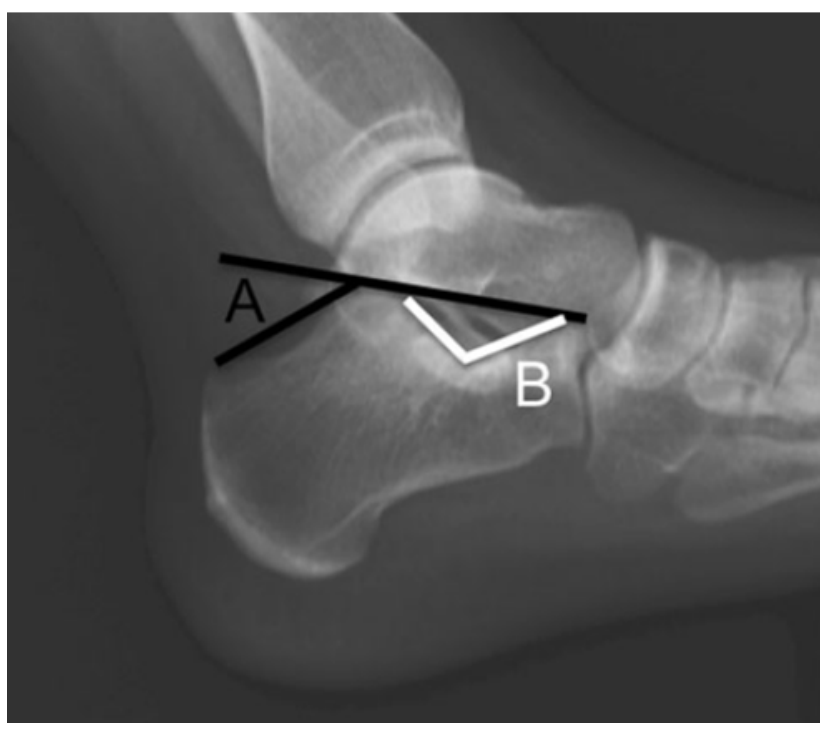

Figure 1. Boehler angle $(A)$ and Gissane angle (B)

described BA as Mortons' method. BA was given different normal ranges for different ethnic populations at studies ${ }^{14}$.

Gissane's angle (GA) is drawn from the superior point of the posterior facet of the calcaneus to the inferior point on the posterior facet to the superior surface of the anterior process of the calcaneus at the main source ${ }^{15}$. It helps to define calcaneal fractures. And it reflects the relationship of the anterior, middle and posterior facets. It differs from $120^{\circ}$ to $145^{\circ}$ in the normal population ${ }^{15,16}$. Boehler and Gissane angles demonstrated on Figure 1.

The measurements were made by a senior orthopedic specialist 14 year-experienced in Group A. And the measurements for Group B were made by a senior orthopedic specialist 14 year-experienced and by a senior radiologist specialist 25 year-experienced. Also Group $\mathrm{B}$ was evaluated for reliability tests. The ICC values were determined. Absolute compliance searched as statistically.

The relationship of the angles with gender, age and side were analyzed. SPSS 20.0 (Windows, IL, USA) software was used for the statistical analysis. KolmogorovSmirnov test was used to determine whether the data in the groups were normally distributed or not. MannWhitney $U$ and Student-t-tests were used to determine whether there is a difference between the mean in BA and GA angles. Mean, standard deviation, minimum-maximum values of normal population and pes 
Table 1. The gender distribution in the groups

\begin{tabular}{|c|c|c|c|}
\hline Study Groups & Gender & Count & Percent \\
\hline \multirow[t]{3}{*}{ Group A (Normal population) $\mathrm{N}=107$} & Female & 37 & $34,6 \%$ \\
\hline & Male & 70 & $65,4 \%$ \\
\hline & Total & 107 & $100,0 \%$ \\
\hline \multirow[t]{3}{*}{ Group B (Pes planus population) $N=26$} & Female & 12 & $46,2 \%$ \\
\hline & Male & 14 & $53,8 \%$ \\
\hline & Total & 26 & $100,0 \%$ \\
\hline
\end{tabular}

Table 2. Boehler-Gissane angles in the groups

\begin{tabular}{llcccc}
\hline Group & & Mean & Std. Deviation & Minimum & Maximum \\
\hline Group A & Boehler Angle (right) N=107 & 36,77 & 3,67 & 23,5 & 42,0 \\
& Boehler Angle (left) N=107 & 33,23 & 7,20 & 18,8 & 49,3 \\
& Gissane Angle (right) N=107 & 110,99 & 10,18 & 87,7 & 136,4 \\
& Gissane Angle (left) N=107 & 108,96 & 9,18 & 88,5 & 129,2 \\
Group B & Boehler Angle (right) N=26 & 36,01 & 7,01 & 26,8 & 55,5 \\
& Boehler Angle (left) N=26 & 35,40 & 6,43 & 26,2 & 53,2 \\
& Gissane Angle (right) N=26 & 116,02 & 8,57 & 97,9 & 130,4 \\
& Gissane Angle (left) N=26 & 111,48 & 6,23 & 101,3 & 124,0
\end{tabular}

Table 3. The ICC values in the reliability study

\begin{tabular}{llc}
\hline Reliability Study (orthopaedist and radiologist) & ICC values \\
\hline Group B & Boehler Angle (right) & 0.996 \\
& Boehler Angle (left) & 0.997 \\
& Gissane Angle (right) & 0.993 \\
& Gissane Angle (left) & 0.987
\end{tabular}

planus group were determined via to dependent $t$-test. Independent $\mathrm{t}$-test was used to compare the unpaired samples as gender. The level of significance for $\mathrm{p}$-value was less 0.05 .

\section{Results}

The gender distribution in the groups was as follows on Table 1. There was no difference between the groups in terms of gender distribution according to the chisquare test $(\mathrm{p}=0.272)$.

BA and GA values were shown on Table 2. In Group $\mathrm{A}$, the mean in $\mathrm{BA}$ for right feet were $36,77^{\circ} \pm 3,67^{\circ}$ $\left(23,5^{\circ}-42,0^{\circ} ; \mathrm{N}=107\right)$. The mean in BA for left feet were $33,23^{\circ} \pm 7,20^{\circ}\left(18,8^{\circ}-49,3^{\circ} ; \mathrm{N}=107\right)$. The mean in GA for right feet were $110,99^{\circ} \pm 10,18^{\circ}\left(87,7^{\circ}\right.$ $\left.136,4^{\circ} ; \mathrm{N}=107\right)$. The mean in GA for left feet were $108,96^{\circ} \pm 9,18^{\circ}\left(88,5^{\circ}-129,2^{\circ} ; \mathrm{N}=107\right)$.

In Group $\mathrm{B}$, the mean in $\mathrm{BA}$ for right feet were $36,01^{\circ} \pm 7,01^{\circ}\left(26,8^{\circ}-55,5^{\circ} ; \mathrm{N}=26\right)$. The mean in BA for left feet were $35,40^{\circ} \pm 6,43^{\circ}\left(26,2^{\circ}-53,2^{\circ} ; N=26\right)$. The mean in GA for right feet were $116,02^{\circ} \pm 8,57^{\circ}$ $\left(97,9^{\circ}-130,4^{\circ} ; \mathrm{N}=26\right)$. The mean in GA for left feet were $111,48^{\circ} \pm 6,23^{\circ}\left(101,3^{\circ}-124,0^{\circ} ; \mathrm{N}=26\right)$. There was no statistical difference between groups and sides $(\mathrm{p}=0.362)$.

The reliability tests were applied for measurements in Group B. Absolute compliance searched as statistically. The ICC values were established in Table 3. The ICC values for BA in right, BA in left, GA in right, GA in left were $0.996,0.997,0.993,0.987$ respectly. All values were significant as statistically for reliability tests.

\section{Discussion}

Calcaneus is the largest bone among tarsal bones. The load which is bearing to feet transmits to the floor by the calcaneus. Measurement on the BA and GA are the predictor points for calcaneal fractures by a significant decreasing ${ }^{16}$. Studies about BA and GA were declared to literature. Ethnic and geographic variability was reported $^{7,17}$. BA and GA have a wide range and distribution in different populations. Seyahi et al were reported BA and GA for the Turkish population. The range 
of $20-46^{\circ}$ for the BA and $100-133^{\circ}$ for the GA can be taken as the normal ranges for the Turkish population ${ }^{8}$.

At the difference for BA and GA on gender, Igbigbi found that the mean in BA of women was greater than $\operatorname{men}^{18}$. But Seyahi et al did not find any statistically significant BA difference between both genders ${ }^{8}$. Also, other studies have not found a difference. There was no difference relationship on the sides according to literature. At all studies about BA and GA, no significant correlation was found between age and calcaneal angles. There was also no significant difference between the mean in calcaneal angles in the different age groups $s^{7,8,15}$.

Rokaya PK et al found an insignificant difference between calcaneal angles and age on the study. By this way, they claimed the relation between calcaneal angles and age may help to diagnose bilateral calcaneal fracture in some conditions ${ }^{16}$. Therefore, keeping angles of BA and GA in hospital memory could help to health professional for regaining the previous anatomic features of calcaneus if bilateral calcaneal fractures were seen.

In our study, we established the mean in BA and GA angles of Caucasian Population as like: BA angles were $36,77^{\circ} \pm 3,67^{\circ}$ for right feet; $33,23^{\circ} \pm 7,20^{\circ}$ for left feet. GA was $110,99^{\circ} \pm 10,18^{\circ}$ for right feet; $108,96^{\circ} \pm 9,18^{\circ}$ for left feet. Our results were consistent with the literature knowledge of our country ${ }^{8}$.

In the second stage of our study, firstly we aimed to determine whether there was the relationship between BA, GA angles and pes planus deformity or not. Two groups as Group A and B were compared for this relation. A second purpose for this stage, we aimed to detect reliability among two observers on calcaneal angles. The measurements on BA and GA made by a senior orthopedist 14 year-experienced and by a senior radiologist specialist 25 year-experienced.

At the literature, there was no study about the relationship between BA, GA and pes planus deformity. As statistical study, we used the Mann-Whitney U test and Student $\mathrm{t}$-test in this comparison. We did not find any relationship between BA, GA angles and pes planus deformity on two groups as Group A and B ( $p=0.362)$.

On the searching of reliability on two observers between a senior orthopedist and a senior radiologist specialist were made. Two-way mixed effects were random and measures effects are fixed. The ICC values were statistically significant on the reliability tests. It was 0.996 for BA in right, 0.997 for BA in left, 0.993 for GA in right, 0.987 for GA in left were.

The forming of a data-bank about the normal anatomical features of the human body can be accepted one of the most important step for medical science of the future. All nations might compose a normal angular configuration for their peoples. These angles might be used to define normals for all body in medical conditions, especially in trauma cases.

In this context, the previous radiographies can be helpful for the diagnosing of the normal angular configuration of the calcaneus. This may be mandatory in medical cases with bilateral calcaneal fractures. We detected the normal values of BA and GA in the Caucasian population in the East region of Turkey. It was consistent with Turkish population. Also, we could not find any relationship between BA, GA and pes planus deformity. We found reliable values on BA and GA with two medical branches on two observers.

\section{References}

1. Davis D, Newton EJ. Calcaneus Fractures. In: StatPearls. Treasure Island (FL): StatPearls Publishing; 2019.

2. Silhanek AD, Ramdass R, Lombardi CM. The effect of primary fracture line location on the pattern and severity of intraarticular calcaneal fractures: a retrospective radiographic study. J Foot Ankle Surg 2006;45:211-9.

3. Shuler FD, Conti SF, Gruen GS, Abidi NA. Wound-healing risk factors after open reduction and internal fixation of calcaneal fractures: does correction of Bohler's angle alter outcomes? Orthop Clin North Am 2001;32:187-92.

4. Loucks C, Buckley R. Bohler's angle: correlation with outcome in displaced intra-articular calcaneal fractures. J Orthop Trauma 1999;13:554-8.

5. Chen MY, Bohrer SP, Kelley TF. Boehler's angle: a reappraisal. Ann Emerg Med 1991;20:122-4.

6. Hauser ML, Kroeker RO. Boehler's angle: a review and study. J Am Podiatry Assoc 1975;65:517-21.

7. Khoshhal KI, Ibrahim AF, Al-Nakshabandi NA, Zamzam MM, Al-Boukai AA, Zamzami MM. Boehler's and Gissane's angles of the calcaneus in the Saudi population. Saudi Med J 2004;25:1967-70.

8. Seyahi A, Uludag S, Koyuncu LO, Atalar AC, Demirhan M. The calcaneal angles in the Turkish population (Türk toplumunda kalkaneus açları. Acta Orthop Traumatol Turc 2009;43(5):406-411.

9. Knight JR, Gross EA, Bradley GH, Bay C, LoVecchio F. Boehler's angle and the critical angle of Gissane are of limited use in diagnosing calcaneus fractures in the ED. Am J Emerg Med 2006;24:423-7. 
10. Boehler L. Diagnosis, pathology, and treatment of fractures of the os calcis. J Bone Joint Surg [Am] 1931;13:75-89.

11. Sanders RW, Clare MP. Fractures of the calcaneus. In: Bucholz RW, Heckman JD, Court-Brown CM, editors. Rockwood and Green's fractures in adults 6th ed. Philadelphia: Lippincott, Williams \& Wilkins; 2001 2293-336.

12. Chaminade B, Zographos S, Uthéza G. Double measurement of the Boehler angle: prognostic value of radiological angles in posterior facet fractures of the calcaneus. Rev Chir Orthop Reparatrice Appar Mot 2001;87:712-7.

13. Dr. Lorenz Bohler. fractures of the os calcis. J Bone Joint Surg [Am] 1932;13:75-89.

14. Cotton FJ HF. Results of fractures of the os calcis. Am J Orthop Surg 1916;14:290-8.
15. Gissane W.Discussion on "Fractures of the os calcis"(Proceedings of the British Orthopaedic Association). J Bone Joint Surg 1947;29:254-255.

16. Rokaya PK, Pokharel RK, Lamichhane AP. Radiographic evaluation of Calcaneal angles in patients presenting to tertiary care center of Nepal. Journal of the Institute of Medicine 2016;38(2-3):33-36.

17. Didia BC, Dimkpa JN. The calcaneal angle in Nigerians. Relationship to sex, age, and side of the body. J Am Podiatr Med Assoc 1999;89:472-4.

18. Igbigbi PS, Mutesasira AN. Calcaneal angle in Ugandans. Clin Anat 2003; 16:328-30. 